\title{
Influence of organic inputs with mineral fertilizer on maize yield and soil microbial biomass dynamics in different seasons in a tropical acrisol
}

\author{
Richard Ansong Omari ${ }^{1} \cdot$ Elsie Sarkodee Addo $^{2} \cdot$ David Martei Matey $^{3} \cdot$ Yoshiharu Fujii $^{2} \cdot$ Shin Okazaki ${ }^{2}$. \\ Yosei Oikawa ${ }^{2} \cdot$ Sonoko Dorothea Bellingrath-Kimura ${ }^{4,5}$
}

Received: 6 May 2019 / Revised: 22 September 2019 / Accepted: 9 October 2019 / Published online: 21 February 2020

(c) The Author(s) 2020

\begin{abstract}
Introduction The practice of co-applying chemical fertilizers (CF) with organic inputs (OIs) as a soil amendment is still low in Ghana, although it has the potential to improve crop yield and soil productivity.

Objectives In a two-year study, we evaluated the effects of co-applying contrasting OIs with and without CF on maize yield and soil chemical and microbial composition.

Methods Aboveground biomasses of Centrosema pubescens (CEN), Pueraria phaseoloides (PUE), and Zea mays (MZE) were amended to an acrisol at $4 \mathrm{tha}^{-1}$ season $^{-1}$. The combined treatments (CEN+, PUE+, and MZE+) were fertilized with basal NPK 15:15:15 at $40 \mathrm{~kg} \mathrm{~N} \mathrm{ha}^{-1}$, followed by topdressing with $\left[\left(\mathrm{NH}_{4}\right)_{2} \mathrm{SO}_{4}\right]$ at $50 \mathrm{~kg} \mathrm{~N} \mathrm{ha}^{-1}$. Sole OI inputs (CEN, PUE, and MZE) did not receive any CF inputs. The controls (CON- and CON+) received 0 and $90 \mathrm{~kg} \mathrm{~N} \mathrm{ha}^{-1}$ season $^{-1}$.

Results The results showed that either sole OIs except for MZE or its combination with CF improved grain yield compared to the CON. Grain yield ranged from $2.1 \mathrm{t} \mathrm{ha}^{-1}$ to $2.6 \mathrm{t} \mathrm{ha}^{-1}$ in the first season versus $0.8 \mathrm{t} \mathrm{ha}^{-1}$ to $1.7 \mathrm{t} \mathrm{ha}^{-1}$ in the second. The MZE+ and CEN+ treatments showed the highest mean grain yields and were similar to CON+. Although CF addition to OIs improved grain yield in all treatments, negative interaction was observed for CEN and PUE as opposed to a positive interaction in the MZE treatment. Co-application of CF with OIs on dissolved organic carbon and nitrogen (DOC) and (EON) dynamics depended on seasonal soil moisture and sampling time. Moreover, co-application of CF with OIs enhanced microbial biomass in CEN but showed minimal and suppressive effects on MZE and PUE amendments, respectively.

Conclusion Overall, the increased grain yield in MZE+, CEN+ and CON+ was attributable primarily to the CF addition. Thus, long term evaluations are recommended for sustainable utilization of MZE and CEN given their minimal responses in the short term in the presence of CFs.
\end{abstract}

Keywords Carbon $\cdot$ Chemical fertilizer $\cdot$ Maize $\cdot$ Nitrogen $\cdot$ Organic input quality $\cdot$ Soil microbial biomass $\cdot$ Yield interactive effects

Sonoko Dorothea Bellingrath-Kimura

belks@zalf.de

1 United Graduate School of Agricultural Science, Tokyo University of Agriculture and Technology, Saiwaicho 3-5-8, Fuchu, Tokyo 183-8509, Japan

2 Institute of Agriculture, Tokyo University of Agriculture and Technology, Saiwaicho 3-5-8, Fuchu, Tokyo 183-8509, Japan

3 Forest and Horticultural Crops Research Centre, Okumaning-Kade, College of Agriculture and Consumer Sciences, University of Ghana, Legon, Ghana
4 Institute of Land Use Systems, Leibniz Centre for Agricultural Landscape Research, Eberswalder Str. 84, 15374 Müencheberg, Germany

5 Institute of Agriculture and Horticulture, Faculty of Life Science, Humboldt-University of Berlin, Albrecht-Thaer-Weg 5, 14195 Berlin, Germany 


\section{Introduction}

The use of organic input (OI) resources for soil productivity management in small-scale farm holdings remains a promising alternative to chemical fertilizers $(\mathrm{CF})$ in Ghana. This is because, prices of CFs is high for an average Ghanaian farmer, even though it continues to be the most widely used fertilization input in the country. Hence, most farmers are compelled to continuously apply CFs at significantly low application rates (Omari et al. 2017), partly resulting in significant low soil fertility levels.

The use of OI as a soil amendment is still low in Ghana, although most farmers recognize its benefits to soils (Boakye-Danquah et al. 2014; Omari et al. 2018a). While farmers' knowledge of OI management is low, the challenge of organic resource availability in some localities and drudgery associated with its application lingers (Omari et al. 2018a). Sole OI applications are unable to meet the timely crop nutrient needs (Gentile et al. 2008), although numerous studies have strongly asserted its significant contributions to the success of the green revolution in Africa (Vanlauwe et al. 2010; Chivenge et al. 2011a). Moreover, the effects of OIs on crop yield might change according to the climate, soil type or season in which they are applied (Ge et al. 2010; Abera et al. 2012; Wei et al. 2016). A practical strategy is to co-apply OI with CFs (Kanonge et al. 2015; Vanlauwe et al. 2010; Yang et al. 2015), amidst the challenge of organic resource availability coupled with farmers' inability to quantify the recommended fertilization rates. The combined application of CFs with OIs is known to supply the immediate and subsequent crop nutrient needs with improvement in overall soil productivity (Chivenge et al. 2011a). Additionally, the burden on farmers in the purchase of CFs may be reduced.

However, till date, most OIs have not been well explored as potential soil amendments (Asante et al. 2017), and studies in that regard have often been sole OI applications with utmost emphasis on crop yield. For example, few reports exist on the use of Centrosema pubescens Benth., a ubiquitous weed resource in Ghana as a soil amendment. Additionally, such soil-related trials have predominantly been based on the resultant soil nutrient contents with limited information on soil microbial dynamics, which play a useful role in soil organic matter (SOM) decomposition, nitrogen $(\mathrm{N})$ cycling and soil aggregates formation (Kamaa et al. 2011). In this respect, results of such studies which primarily focus on the above and below-ground plant parameters in separate experiments may appear less convincing in the quest to recommend potential OIs to farmers to improve soil fertility.

It is well recognized that soil microbial composition plays an active role in soil $\mathrm{N}$ dynamics. The availability of $\mathrm{N}$ from OIs will depend on the existence and activities of microbial organisms. For example, fungi and bacteria are known to exhibit different $\mathrm{N}$ demands and thereby influence the decomposition of various organic materials (Keiblinger et al. 2010; Sinsabaugh et al. 2010). Additionally, studies elsewhere have shown that fertilization regimes influence soil bacterial populations (Shen et al. 2010; Kamaa et al. 2011). In both studies, it was reported that bacterial community structure in chemical fertilization treatment was significantly smaller compared to organic manure or organic manure plus CF treatments. Moreover, it has been well acknowledged that enhanced microbial activity partially connote improved crop yield (Kamaa et al. 2011; Partey et al. 2014; Omari et al. 2016).

The objective of this study was to assess the effects of short-term repeated application (2 seasons) of contrasting OIs in combination with or without $\mathrm{CF}$ on maize yield and microbial biomass in a tropical arable soil. The innovativeness of this study is the field trials in Ghanaian conditions simultaneously focussing on crop yield and soil microbial dynamics following contrasting OI input with or without CFs.

\section{Materials and methods}

\section{Site description}

A field study was carried out at the Forest and Horticultural Crops Research Center (FOHCREC), University of GhanaKade $\left(6^{\circ} 8^{\prime} 48^{\prime \prime} \mathrm{N}, 0^{\circ} 53^{\prime} 58^{\prime \prime} \mathrm{W} ; 170 \mathrm{~m}\right.$ above sea level (a.s.l.)) in the Eastern region of Ghana. The site receives bimodal mean annual precipitation of $1300-1500 \mathrm{~mm}$, allowing for two cropping seasons in a year. The area has a mean annual temperature of $26{ }^{\circ} \mathrm{C}$ (Fig. 1). The soil in the study area is an Acrisol (FAO/ISRIC/ISSS 1998), characterized by a fine granular structure with friable consistency (Adjei-Gyapong and Asiamah 2002). Table 1 shows the basic soil properties of the study site. The area is notable for plantation crop production predominantly oil palm, rubber and cocoa. The first season trial was conducted during the long rainy season (March-July, 2016), while the second trial spanned from September 2016 to January 2017. The field for the study had previously been cultivated with maize.

\section{Collection and preparation of organic materials}

The OIs used in this study were aboveground biomasses (stalk, twig, petioles, leaves, and stems) of Butterfly pea [ $C$. pubescens Benth.], Tropical Kudzu [Pueraria phaseoloides (Roxb.) Benth.], and Maize stover [Zea mays L.], henceforth referred to as CEN, PUE and MZE, respectively. These are readily available but largely underutilized organic materials, 
Fig. 1 Mean monthly rainfall (1983-2014) and mean temperature (1983-2014) in the study area

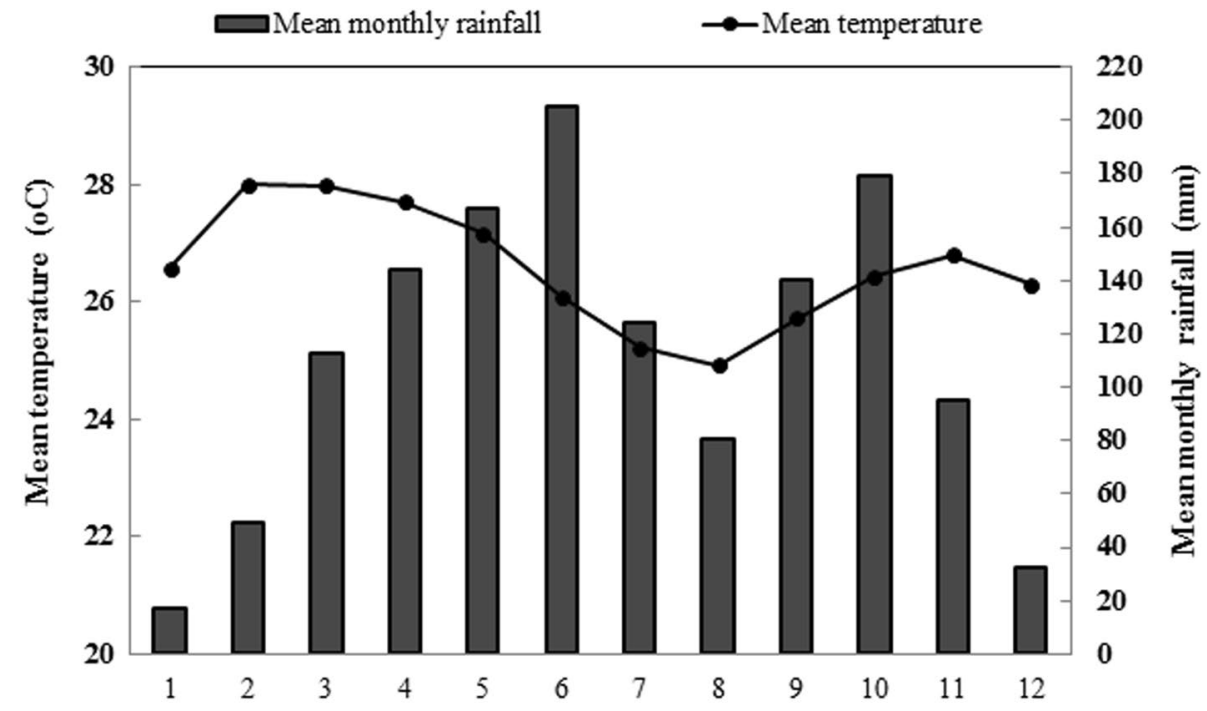

Months in a year January [(1)-December (12)]
Table 1 Physicochemical properties of the study site soil

\begin{tabular}{ll}
\hline Parameter (Unit) & $\begin{array}{l}\text { Site name } \\
\text { Kade }\end{array}$ \\
\hline Sand $\left(\mathrm{g} \mathrm{kg}^{-1}\right)$ & 42.4 \\
$\mathrm{Silt}\left(\mathrm{g} \mathrm{kg}^{-1}\right)$ & 49.4 \\
$\mathrm{Clay}\left(\mathrm{g} \mathrm{kg}^{-1}\right)$ & 8.2 \\
$\mathrm{pH}\left(\mathrm{H}_{2} \mathrm{O}\right)$ & 6.2 \\
Total organic carbon $\left(\mathrm{mg} \mathrm{kg}^{-1}\right)$ & $653.2 \pm 14$ \\
Extractable organic nitrogen $\left(\mathrm{mg} \mathrm{kg}^{-1}\right)$ & $114.6 \pm 21$ \\
Total C $\left(\mathrm{g} \mathrm{kg}^{-1}\right)$ & $15.4 \pm 1.5$ \\
Total nitrogen $\left(\mathrm{g} \mathrm{kg}^{-1}\right)$ & $2.7 \pm 0.3$ \\
$\mathrm{CN} \mathrm{ratio}^{-1}$ & 5.7 \\
Available P $\left(\mathrm{mg} \mathrm{kg}^{-1}\right)$ & $12.6 \pm 1.9$ \\
$\mathrm{NH}_{4}{ }^{+}\left(\mathrm{mg} \mathrm{kg}^{-1}\right)$ & $16.41 \pm 0.1$ \\
$\mathrm{NO}_{3}^{-}\left(\mathrm{mg} \mathrm{kg}^{-1}\right)$ & $94.1 \pm 15.3$ \\
Organic matter $(\%)^{-1}$ & 3.1 \\
\hline
\end{tabular}

which were collected from farmers' field around the study site and sun-dried to their constant weights. Subsamples of each sample were oven-dried at $60{ }^{\circ} \mathrm{C}$ for $72 \mathrm{~h}$, ball-milled to powder and analyzed for litter quality in triplicates. The quality characteristics comprised polyphenols, available phosphorus (P), available potassium (K), total carbon (TC) and total nitrogen (TN) (Table 2), as explained in our previous research (Omari et al. 2016).

\section{The experimental procedure, design, and management}

The site was first cleared of weeds, followed by debris removal and tilling to a depth of $20 \mathrm{~cm}$. The experiment was laid out in a split-plot design with four replications per treatment involving OIs as the main plot factor and mineral fertilizer application as a sub-plot factor. The main plot factor comprised OI application, namely; CEN, PUE, MZE, and control. The main plot measured $8 \mathrm{~m}$ by $6 \mathrm{~m}$, while the subplot was $4 \mathrm{~m}$ by $6 \mathrm{~m}$. At the onset of the rains in both seasons ( 6 weeks before sowing), the aboveground biomasses of each sun-dried OIs were chopped into smaller units $(<10 \mathrm{~mm})$ and hand incorporated to a soil depth of $15 \mathrm{~cm}$ at a rate of $4 \mathrm{tha}^{-1}$. In the sub-plots with $\mathrm{CF}, \mathrm{N}$ was applied as NPK 15:15:15 and $\left[\left(\mathrm{NH}_{4}\right)_{2} \mathrm{SO}_{4}\right]$ at $90 \mathrm{~kg} \mathrm{~N}$ $\mathrm{ha}^{-1}$ per growing season. The amount was split applied at $40 \mathrm{~kg} \mathrm{~N} \mathrm{ha}^{-1}$ as NPK 15:15:15, 2 weeks after sowing. This
Table 2 Chemical quality composition of organic residues

\begin{tabular}{lllllll}
\hline Organic residue & $\mathrm{TC}\left(\mathrm{g} \mathrm{kg}^{-1}\right)$ & $\mathrm{TN}\left(\mathrm{g} \mathrm{kg}^{-1}\right)$ & $\mathrm{CN}$ & $\mathrm{PP}\left(\mathrm{mg} \mathrm{GAE} \mathrm{g}^{-1}\right)$ & $\mathrm{P}\left(\mathrm{mg} \mathrm{kg}^{-1}\right)$ & $\mathrm{K}\left(\mathrm{mg} \mathrm{kg}^{-1}\right)$ \\
\hline Centrosema (CEN) & $443.21^{\mathrm{b}}$ & $35.11^{\mathrm{a}}$ & 13 & $2.62^{\mathrm{c}}$ & $30.6^{\mathrm{a}}$ & $41.3^{\mathrm{b}}$ \\
Pueraria (PUE) & $415.35^{\mathrm{c}}$ & $24.01^{\mathrm{b}}$ & 17 & $4.41^{\mathrm{b}}$ & $34.2^{\mathrm{a}}$ & $46.2^{\mathrm{a}}$ \\
Maize (MZE) & $520.21^{\mathrm{a}}$ & $21.14^{\mathrm{c}}$ & 24 & $12.30^{\mathrm{a}}$ & $17.9^{\mathrm{b}}$ & $28.8^{\mathrm{c}}$ \\
\hline
\end{tabular}

Values are the means of three replicates. Means with different letters in the same column are significantly different from each other according to Tukey test at 5\% probability level. TC total carbon, TN total nitrogen, $C N$ ratio carbon-to-nitrogen ratio, $P P$ polyphenol 
was followed by a subsequent top dressing as $\left[\left(\mathrm{NH}_{4}\right)_{2} \mathrm{SO}_{4}\right]$ at $50 \mathrm{~kg} \mathrm{~N} \mathrm{ha}^{-1} 6$ weeks later. The CEN, PUE and MZE represent sole applications of OIs, while their respective counterparts receiving mineral $\mathrm{N}$ fertilizer are denoted as $\mathrm{CEN}+$, PUE+ and MZE+. The positive control (CON+) received sole $\mathrm{CF}$ as NPK 15:15:15 and $\left[\left(\mathrm{NH}_{4}\right)_{2} \mathrm{SO}_{4}\right]$ at $90 \mathrm{~kg} \mathrm{~N} \mathrm{ha}^{-1}$ season $^{-1}$. The control (CON-) received no resource input. Buffer plots of $(1.5 \mathrm{~m})$ were left between the blocks to minimize cross-border effects. The test crop (Zea mays), Obaatanpa variety, was sown three seeds per hill and later thinned to two at a spacing of $80 \mathrm{~cm} \times 40 \mathrm{~cm}$. All seeds were sown by hand drill into $5 \mathrm{~cm}$ depth rows. Each plot was regularly hand weeded to minimize any impact of weed pressure on maize performance. All agronomic practices were carried out based on the local practices except the use of herbicides which was only employed at the initial land preparation stage. Maize biomass was determined two times; at tassel and physiological maturity stage. The total dry weight biomass of six record plants per plot of the test crop was determined at tassel. At physiological maturity stage, twelve maize stands per plot were sampled at random using the simple random technique (Gomez and Gomez 1984). The whole maize straw ( $5 \mathrm{~cm}$ from the topsoil) were chopped into smaller units $(<50 \mathrm{~mm})$, oven-dried at $105{ }^{\circ} \mathrm{C}$ for $72 \mathrm{~h}$ to attain constant dry weight. Grain yields were determined at $12 \%$ moisture content.

\section{Soil samplings and analyses}

Soil samplings were done before treatment application, at tassel and immediately after harvesting. Soil sampling was done at $0-15 \mathrm{~cm}$ depth from up to ten points in each plot, bulked and kept frozen at $-20{ }^{\circ} \mathrm{C}$ before analyses. Bulked samples were first passed through a $2 \mathrm{~mm}$ mesh, before transporting under the ice to Tokyo for further biochemical measurements. Soil TC and TN were analyzed by dry combustion using a CN analyzer (Sumika Chemical Analysis Service Ltd., Osaka, Japan). Soil pH was measured in water suspensions at a solid-to-liquid ratio of 1:2.5 using Beckman PKG$260 \mathrm{pH}$ meter (Beckman Coulter Instruments Inc., Fullerton, USA). For the particle size distribution, $10 \mathrm{~g}$ soil sample was first digested with $100 \mathrm{ml}$ hydrogen peroxide, followed by the determination of sand, silt and clay proportions with laser diffraction particle size analyzer (SALD-2300, Shimadzu Corporation, Kyoto, Japan). The SOM was estimated by loss on ignition method (Nelson and Sommers 1996), after exposing $5 \mathrm{~g}$ soil sample at $550^{\circ} \mathrm{C}$ in an Electric muffle furnace (FUL 230 FA, Advantech Toyo Co., Ltd, Tokyo Japan).

Soil mineral $\mathrm{N}\left(\mathrm{NH}_{4}{ }^{+}-\mathrm{N}\right.$ and $\left.\mathrm{NO}_{3}{ }^{-}-\mathrm{N}\right)$ was quantified by first extracting $10 \mathrm{~g}$ of moist soil with $100 \mathrm{~mL}$ of $2 \mathrm{M} \mathrm{KCl}$ solution. The $\mathrm{NH}_{4}{ }^{+}-\mathrm{N}$ and $\mathrm{NO}_{3}{ }^{-}-\mathrm{N}$ contents in the filtrate were subsequently measured with the UV-VIS spectrophotometer (Shimadzu UV mini 1240, Shimadzu Corporation,
Kyoto, Japan) by following procedures described by Parsons et al. (1984) and US EPA (1983), respectively. Available $\mathrm{P}$ content in soil was measured using the Truog-soluble $\mathrm{P}$ method (Truog 1930). The modified fumigation-extraction method was used to evaluate the microbial biomass in soil (Hobbie 1998). Briefly, soil samples marked for fumigation were exposed to alcohol-free chloroform for $72 \mathrm{~h}$ in airtight flasks, while non-fumigated samples were kept frozen. Dissolved organic $\mathrm{C}$ (DOC) in the fumigated and non-fumigated samples were first extracted with $0.5 \mathrm{M} \mathrm{K}_{2} \mathrm{SO}_{4}$ and analyzed with TOC-L (TOC-L CPH, Shimadzu Corporation, Kyoto, Japan). Additionally, the dissolved organic N (EON) in the same solution was measured with TNM-L analyser (TOC-L $\mathrm{CPH}$, Shimadzu Corporation, Kyoto, Japan) following procedures as described by Ros et al. (2009). Microbial biomass $\mathrm{C}$ and $\mathrm{N}$ (MBC and MBN) in soil were calculated from the difference between fumigated and non-fumigated samples by converting the dissolved organic $\mathrm{C} \& \mathrm{~N}$ to $\mathrm{MBC}$ and $\mathrm{MBN}$, respectively. The calibration value for $\mathrm{MBC}$ was 0.45 (Joergensen 1996), while that of MBN was 0.54, according to Brookes et al. (1985). All soil analyses were conducted in four replicates.

\section{Calculation of interactive effects of inputs on yield}

The interactive effects of OIs and CF inputs, which represent the extra yield obtained following the combined application of OIs and $\mathrm{N}$ fertilizers compared with the sum of the two when added separately (Vanlauwe et al. 2001) was calculated for each treatment as defined in Vanlauwe et al. (2001).

$$
\begin{aligned}
\text { Interactive effects }= & Y_{\mathrm{COM}}-\mathrm{Y}_{\mathrm{CON}}-\left(\mathrm{Y}_{\mathrm{OIS}}-\mathrm{Y}_{\mathrm{CON}}\right) \\
& -\left(\mathrm{Y}_{\mathrm{IF}}-\mathrm{Y}_{\mathrm{CON}}\right)
\end{aligned}
$$

Where $\mathrm{Y}_{\mathrm{COM}}$ stands for the yield of combined treatment, $\mathrm{Y}_{\mathrm{CON}}$ stands for the yield of no input control treatment,

$\mathrm{Y}_{\mathrm{OIS}}$ stands for the yield of sole organic residue treatment, and

$\mathrm{Y}_{\mathrm{IF}}$ stands for the yield of mineral fertilizer treatment (positive control).

\section{Statistical analyses}

Statistical analyses were performed with SAS software (Statistical Analysis System, version 9.0). Data were subjected to analysis of variance (ANOVA) to determine the differences between contrasting OIs with or without CFs and their interaction on mineral $\mathrm{N}$ and microbial composition of the resultant soil. Mean differences among the treatments were compared using the Tukey's Honest Significant Difference (HSD) test at $\mathrm{P}<0.05$. 


\section{Results}

\section{Straw and grain yield-differences among treatments in both seasons}

CF with or without OIs significantly $(\mathrm{P}<0.05)$ increased straw yield at tassel and harvest in both growing seasons (Table 3). Higher values in straw yield were recorded in the first season compared to the second season at both sampling times. The combined application of OIs with CF resulted in 40-88\% higher aboveground biomass yield compared to sole OIs in both seasons. In the first season, CEN+ and PUE+ showed the highest average aboveground biomass yield of $6.0 \mathrm{tha}^{-1}$ and $5.7 \mathrm{tha}^{-1}$ and were $25 \%$ and $90 \%$ higher than the control with or without $\mathrm{N}$ fertilizer $(\mathrm{CON}+, \mathrm{CON}-)$ treatments, respectively. In the second season, $\mathrm{CON}+$ and $\mathrm{CEN}+$ had higher average biomass yield, with values ranging from $2.7 \mathrm{tha}^{-1}$ to $4.3 \mathrm{tha}^{-1}$ and $3.3 \mathrm{t} \mathrm{ha}^{-1}$ to $3.8 \mathrm{tha}^{-1}$ from tassel to harvest, respectively.

Grain yield ranged from $2.1 \mathrm{t} \mathrm{ha}^{-1}$ to $2.6 \mathrm{t} \mathrm{ha}^{-1}$ in the first season compared to $0.8 \mathrm{t} \mathrm{ha}^{-1}$ to $1.7 \mathrm{t} \mathrm{ha}^{-1}$ in the second season (Table 4). Mean grain yield in the first season was $84 \%$ higher compared to the second season. The combined treatments significantly showed higher average maize grain yield response compared to the sole OI amendments. In the first season, yield increases in the CEN+, MZE+, and $\mathrm{CON}+$ treatments were $2.6 \mathrm{tha}^{-1}, 2.5 \mathrm{t} \mathrm{ha}^{-1}$ and 2.4 $\mathrm{t} \mathrm{ha}^{-1}$, respectively and were about $20 \%$ higher compared to CON-. However, in the second season, MZE+ showed significantly greater grain yield value of $1.7 \mathrm{t} \mathrm{ha}^{-1}$ and was almost twice higher than $\mathrm{CON}-$. The average grain
Table 4 Maize grain yield following two-season continuous application of contrasting OIs with or without chemical fertilizers

\begin{tabular}{|c|c|c|c|c|}
\hline \multirow[t]{2}{*}{ Treatment } & \multirow[t]{2}{*}{$\mathrm{N}$ fertilizer } & \multicolumn{3}{|c|}{ Grain yield $\left(\mathrm{t} \mathrm{ha}^{-1}\right)$} \\
\hline & & First & Second & Average \\
\hline \multirow[t]{2}{*}{$\mathrm{CON}$} & 0 & $2.1 \pm 0.05^{\mathrm{c}}$ & $0.9 \pm 0.01^{\mathrm{f}}$ & $1.5 \pm 0.03$ \\
\hline & 90 & $2.4 \pm 0.14^{\mathrm{a}}$ & $1.6 \pm 0.02^{\mathrm{b}}$ & $2.0 \pm 0.02$ \\
\hline \multirow[t]{2}{*}{ CEN } & 0 & $2.4 \pm 0.07^{\mathrm{ab}}$ & $1.2 \pm 0.01^{\mathrm{e}}$ & $1.8 \pm 0.04$ \\
\hline & 90 & $2.6 \pm 0.05^{\mathrm{a}}$ & $1.5 \pm 0.01^{\mathrm{c}}$ & $2.0 \pm 0.02$ \\
\hline \multirow[t]{2}{*}{ PUE } & 0 & $2.2 \pm 0.15^{\mathrm{bc}}$ & $1.3 \pm 0.03^{\mathrm{d}}$ & $1.7 \pm 0.09$ \\
\hline & 90 & $2.4 \pm 0.12^{\mathrm{ab}}$ & $1.6 \pm 0.03^{\mathrm{b}}$ & $1.9 \pm 0.06$ \\
\hline \multirow[t]{2}{*}{ MZE } & 0 & $2.1 \pm 0.08^{c}$ & $0.8 \pm 0.01^{\mathrm{g}}$ & $1.5 \pm 0.03$ \\
\hline & 90 & $2.5 \pm 0.011^{\mathrm{a}}$ & $1.7 \pm 0.03^{\mathrm{a}}$ & $2.1 \pm 0.01$ \\
\hline Means & & 2.4 & 1.3 & \\
\hline MSD & & 0.21 & 0.04 & \\
\hline $\mathrm{CV}(\%)$ & & 3.9 & 1.5 & \\
\hline $\mathrm{R}^{2}$ & & 0.86 & 0.99 & \\
\hline
\end{tabular}

Different letters $(\mathrm{a}, \mathrm{b})$ within the same column indicate treatments with significant differences $(\mathrm{P}<0.05)$

Treatments codes: CON control, CEN Centrosema pubescens, PUE Pueraria pubescens, MZE Zea mays, MSD minimum significant difference, $C V$ coefficient of variation

yield among the combined treatments was in the order $\mathrm{MZE}+>\mathrm{CEN}+>\mathrm{PUE}+$. Moreover, the average maize yield response following $\mathrm{CF}$ addition was highest in MZE, followed by CON, PUE, and CEN (Table 5). It increased from 16.0 to $52.9 \%$ for MZE, 12.5 to $43.8 \%$ for CON, $8.3-18.8 \%$ for PUE and $7.7-20.0 \%$ for CEN from the first to second seasons, respectively.
Table 3 Maize straw yields following a two-season continuous application of contrasting OIs with or without chemical fertilizers

\begin{tabular}{|c|c|c|c|c|c|c|c|}
\hline \multirow[t]{3}{*}{ Treatment } & \multicolumn{7}{|c|}{ Straw yield $\left(\mathrm{t} \mathrm{ha}^{-1}\right)$} \\
\hline & \multicolumn{4}{|l|}{ Tassel } & \multicolumn{3}{|l|}{ Harvest } \\
\hline & $\mathrm{N}$ fertilizer & First & Second & Average & First & Second & Average \\
\hline \multirow[t]{2}{*}{$\mathrm{CON}$} & 0 & $2.8 \pm 0.3^{\mathrm{de}}$ & $1.6 \pm 0.2^{\mathrm{e}}$ & $2.2 \pm 0.2$ & $3.1 \pm 0.3^{\mathrm{d}}$ & $2.1 \pm 0.1^{\mathrm{c}}$ & $2.6 \pm 0.2$ \\
\hline & 90 & $4.2 \pm 0.6^{\mathrm{bc}}$ & $2.7 \pm 0.2^{\mathrm{c}}$ & $3.5 \pm 0.3$ & $4.8 \pm 0.6^{\mathrm{b}}$ & $4.3 \pm 1.3^{\mathrm{a}}$ & $4.6 \pm 0.9$ \\
\hline \multirow[t]{2}{*}{ CEN } & 0 & $3.3 \pm 0.4^{\mathrm{de}}$ & $1.9 \pm 0.2^{\mathrm{d}}$ & $2.6 \pm 0.3$ & $3.7 \pm 0.5^{\mathrm{cd}}$ & $2.1 \pm 0.2^{\mathrm{c}}$ & $2.9 \pm 0.3$ \\
\hline & 90 & $5.6 \pm 0.5^{\mathrm{a}}$ & $3.3 \pm 0.4^{\mathrm{ab}}$ & $4.5 \pm 0.4$ & $6.4 \pm 0.5^{\mathrm{a}}$ & $3.8 \pm 0.5^{\mathrm{ab}}$ & $5.1 \pm 0.5$ \\
\hline \multirow[t]{2}{*}{ PUE } & 0 & $3.5 \pm 0.4^{\mathrm{cd}}$ & $2.0 \pm 0.2^{\mathrm{d}}$ & $2.8 \pm 0.3$ & $3.9 \pm 0.4^{\mathrm{c}}$ & $1.8 \pm 0.2^{\mathrm{c}}$ & $2.9 \pm 0.3$ \\
\hline & 90 & $5.5 \pm 0.5^{\mathrm{a}}$ & $3.5 \pm 0.2^{\mathrm{a}}$ & $4.5 \pm 0.4$ & $6.0 \pm 0.5^{\mathrm{a}}$ & $3.0 \pm 0.1^{\mathrm{abc}}$ & $4.5 \pm 0.3$ \\
\hline \multirow[t]{2}{*}{ MZE } & 0 & $2.6 \pm 0.5^{\mathrm{e}}$ & $1.9 \pm 0.2^{\mathrm{d}}$ & $2.3 \pm 0.3$ & $3.3 \pm 0.5^{\mathrm{cd}}$ & $2.7 \pm 0.1^{\mathrm{bc}}$ & $3.0 \pm 0.3$ \\
\hline & 90 & $4.9 \pm 0.5^{\mathrm{ab}}$ & $3.1 \pm 0.1^{\mathrm{b}}$ & $4.0 \pm 0.3$ & $5.8 \pm 0.5^{\mathrm{a}}$ & $3.8 \pm 0.8^{\mathrm{ab}}$ & $4.8 \pm 0.7$ \\
\hline Means & & 4.0 & 2.5 & & 4.6 & 2.9 & \\
\hline MSD & & 0.8 & 0.3 & & 0.8 & 1.5 & \\
\hline $\mathrm{CV}(\%)$ & & 10.7 & 8.5 & & 12.9 & 21.2 & \\
\hline $\mathrm{R}^{2}$ & & 0.9 & 0.9 & & 0.9 & 0.7 & \\
\hline
\end{tabular}

Different letters $(\mathrm{a}, \mathrm{b})$ within the same column indicate treatments with significant differences $(\mathrm{P}<0.05)$

Treatments codes: CON control, CEN Centrosema pubescens, PUE Pueraria pubescens, MZE Zea mays, $M S D$ minimum significant difference, $C V$ coefficient of variation 
Table 5 Percentage change in grain yield following chemical fertilizer addition on contrasting OIs

\begin{tabular}{lccl}
\hline Treatment & \multicolumn{3}{l}{ Change in grain yield $(\%)$} \\
\cline { 2 - 4 } & First & Second & Average \\
\hline CON & 12.5 & 43.8 & $\mathbf{2 5 . 0}$ \\
CEN & 7.7 & 20.0 & $\mathbf{1 0 . 0}$ \\
PUE & 8.3 & 18.8 & $\mathbf{1 0 . 5}$ \\
MZE & 16.0 & 52.9 & $\mathbf{2 8 . 6}$ \\
Average & 11.1 & 33.9 & $\mathbf{1 8 . 5}$ \\
\hline
\end{tabular}

Treatments codes: CON control, CEN Centrosema pubescens, PUE

Pueraria pubescens, MZE Zea mays
Negative interaction was observed for CEN and PUE with $\mathrm{CF}$, while MZE with $\mathrm{CF}$ resulted in enhanced maize grain yield response in both seasons (Fig. 2). The interactive effects of co-applying $\mathrm{CF}$ with OIs on grain yield were more pronounced in the second season compared to the first. The CEN and PUE showed a significant negative shift from -0.09 to -0.28 and -0.07 to -0.30 from first to the second season, respectively. In case of MZE, the interactive effects increased from 0.09 to 0.26 from the first to the second season.
Fig. 2 Mean interactive effects of combining organic and chemical fertilizer sources on grain yields. Black bars = first season; white bars $=$ second season Error bars reperesent standard deviation of four replications. Treatment codes: $C O N$ control, CEN Centrosema pubescens, PUE Pueraria pubescens, MZE Zea mays

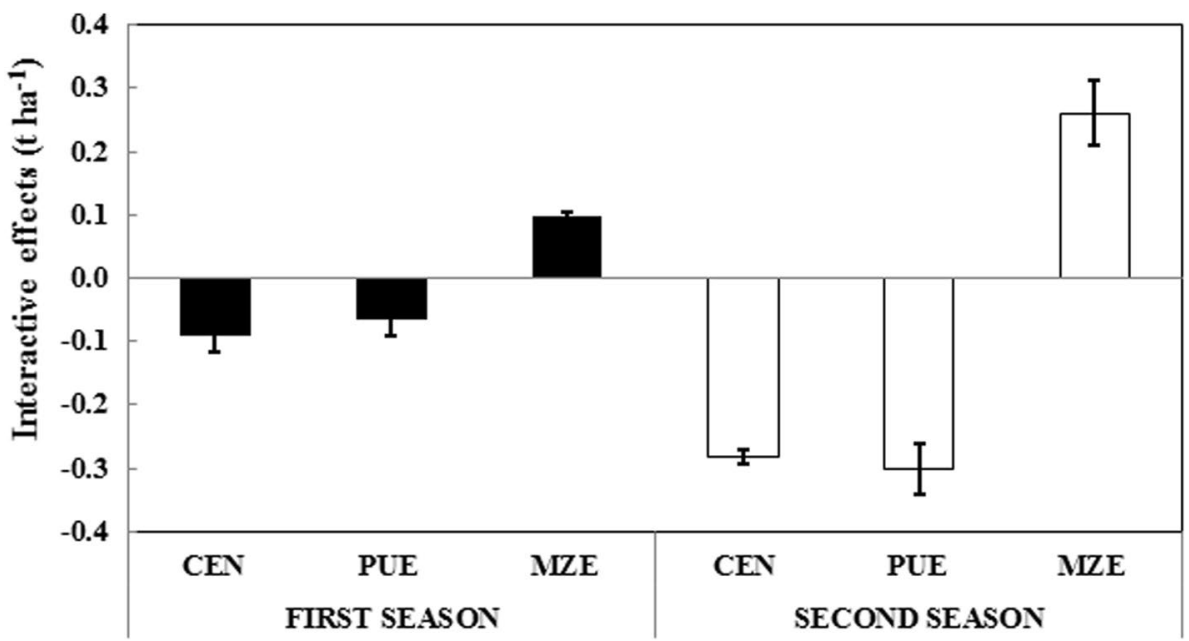

Treatment

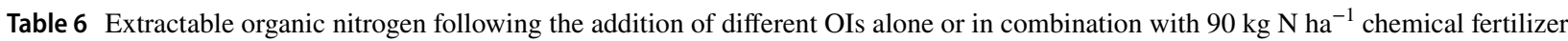

\begin{tabular}{|c|c|c|c|c|c|c|c|}
\hline \multicolumn{8}{|c|}{ Extractable organic nitrogen $\left(\mathrm{mg} \mathrm{kg}^{-1}\right)$} \\
\hline \multirow[t]{2}{*}{ Treatment } & \multirow[t]{2}{*}{$\mathrm{N}$ fertilizer } & \multicolumn{3}{|l|}{ Tassel } & \multicolumn{3}{|l|}{ Harvest } \\
\hline & & First & Second & Average & First & Second & Average \\
\hline \multirow[t]{2}{*}{$\mathrm{CON}$} & 0 & $118.5 \pm 3.8^{\mathrm{abc}}$ & $82.5 \pm 1.5^{\mathrm{a}}$ & $100.5 \pm 2.7$ & $92.8 \pm 4.4^{\mathrm{c}}$ & $80.7 \pm 6.1^{\mathrm{cd}}$ & $86.8 \pm 5.3$ \\
\hline & 90 & $90.5 \pm 8.8^{\mathrm{d}}$ & $80.7 \pm 2.4^{\mathrm{a}}$ & $85.6 \pm 5.6$ & $88.8 \pm 0.2^{\mathrm{c}}$ & $90.7 \pm 3.3^{\mathrm{b}}$ & $89.8 \pm 1.8$ \\
\hline \multirow[t]{2}{*}{ CEN } & 0 & $100.6 \pm 3.3^{\mathrm{cd}}$ & $75.6 \pm 13.9^{\mathrm{a}}$ & $88.1 \pm 8.6$ & $106.0 \pm 2.5^{\mathrm{ab}}$ & $79.4 \pm 15.6^{\mathrm{d}}$ & $92.7 \pm 9.1$ \\
\hline & 90 & $121.5 \pm 8.0^{\mathrm{ab}}$ & $77.4 \pm 12.8^{\mathrm{a}}$ & $99.5 \pm 10.4$ & $110.6 \pm 8.3^{\mathrm{a}}$ & $88.5 \pm 4.5^{\mathrm{bc}}$ & $99.6 \pm 6.4$ \\
\hline \multirow[t]{2}{*}{ PUE } & 0 & $108.0 \pm 5.3^{\mathrm{abcd}}$ & $67.2 \pm 4.2^{\mathrm{a}}$ & $87.6 \pm 4.8$ & $98.2 \pm 3.2^{\mathrm{bc}}$ & $82.2 \pm 5.8^{\mathrm{cd}}$ & $90.2 \pm 4.5$ \\
\hline & 90 & $124.8 \pm 9.3^{\mathrm{a}}$ & $69.2 \pm 2.3^{\mathrm{a}}$ & $97.0 \pm 5.8$ & $89.5 \pm 2.2^{\mathrm{c}}$ & $95.7 \pm 3.8^{\mathrm{b}}$ & $92.6 \pm 3.0$ \\
\hline \multirow[t]{2}{*}{ MZE } & 0 & $103.9 \pm 1.7^{\mathrm{bcd}}$ & $67.1 \pm 1.8^{\mathrm{a}}$ & $85.5 \pm 1.8$ & $98.6 \pm 1.0^{\mathrm{bc}}$ & $76.8 \pm 6.3^{\mathrm{d}}$ & $87.7 \pm 3.7$ \\
\hline & 90 & $110.6 \pm 4.5^{\mathrm{abc}}$ & $80.5 \pm 3.0^{\mathrm{a}}$ & $95.6 \pm 3.8$ & $95.7 \pm 2.4^{\mathrm{bc}}$ & $106.4 \pm 2.8^{\mathrm{a}}$ & $101.1 \pm 2.6$ \\
\hline Means & & 109.8 & 75.3 & & 97.5 & 87.6 & \\
\hline MSD & & 18.9 & 21.5 & & 11.8 & 7.9 & \\
\hline $\mathrm{CV}(\%)$ & & 6.0 & 9.9 & & 4.2 & 3.1 & \\
\hline $\mathrm{R}^{2}$ & & 0.81 & 0.52 & & 0.84 & 0.95 & \\
\hline
\end{tabular}

Different letters (a, b, c, d) in the same column indicate treatments with significant differences within the same season $(\mathrm{P}<0.05)$

Treatments codes: $C O N$ control, $C E N$ Centrosema pubescens, $P U E$ Pueraria pubescens, $M Z E$ Zea mays, $M S D$ minimum significant difference, $C V$ coefficient of variation 


\section{Soil carbon and nitrogen contents}

Treatment application resulted in greater EON in the first season compared to the second at tassel and harvest (Table 6). At tassel, while treatment application during the first season resulted in significant differences in EON content, no statistical significance was observed in the second. At harvest, during the first season, $\mathrm{CEN}+$ and CEN- showed higher significant EON values of $110.6 \mathrm{mg} \mathrm{kg}^{-1}$ and $106.0 \mathrm{mg} \mathrm{kg}^{-1}$, respectively while the least was observed in $\mathrm{CON}+$. Moreover, at harvest during the second season, the highest and lowest EON values were recorded in MZE+ and MZE- treatments, respectively.

In contrast to the EON, the addition of OIs, alone or with $\mathrm{CF}$ increased the average mineral $\mathrm{N}$ in the second season compared to the first (Fig. 3a). However, at harvest, values reported in the first season were almost twice higher compared to the second season, i.e. average of $274.9 \mathrm{mg} \mathrm{kg}^{-1}$ against $172.7 \mathrm{mg} \mathrm{kg}^{-1}$ for the first and second seasons, respectively (Fig. 3b). At tassel, the highest mineral N was observed in PUE+ and CON+ during the first and second seasons, respectively. Moreover at harvest, while $\mathrm{CEN}+$ showed the highest mineral $\mathrm{N}$ of $336.5 \mathrm{mg} \mathrm{kg}^{-1}$ in the first season, PUE+ showed the highest mineral $\mathrm{N}$ of $193.7 \mathrm{mg} \mathrm{kg}^{-1}$ in the second season.

Irrespective of treatment type, the first season recorded higher mean DOC of $496.6 \mathrm{mg} \mathrm{kg}^{-1}$ compared to $336.8 \mathrm{mg} \mathrm{kg}^{-1}$ in the second season at tassel (Table 7). An inverse trend was however observed at harvest, where twice higher values were recorded in the second season relative to the first season. At tassel, sole OI application showed higher DOC content compared to their respective combinations with CF. For example, CEN-, MZE-, and PUE- had an average DOC of $448.1 \mathrm{mg} \mathrm{kg}^{-1}, 424.2 \mathrm{mg} \mathrm{kg}^{-1}$, and $420.2 \mathrm{mg} \mathrm{kg}^{-1}$, respectively and were higher than their corresponding combined applications with $\mathrm{CF}$. This translated into higher soil DOC/EON ratios in the sole OI treatments compared to their corresponding combined treatments at tassel. The highest average DOC content at tassel was in sole CEN- treatment while the lowest, which was similar to MZE+ and PUE+, was observed in CEN+. However, at harvest during the second season, the trend reversed for all OI amendments, except MZE where no significant changes were observed. The PUE+ amendment recorded the highest average DOC of $387.9 \mathrm{mg} \mathrm{kg}^{-1}$ while the least was in $\mathrm{CEN}$ - treatment.
Fig. 3 Soil inorganic nitrogen content a tassel and $\mathbf{b}$ at harvest in both growing seasons. Treatment codes: $C O N$ control, CEN Centrosema pubescens, PUE Pueraria phaseoloides, MZE Zea mays. Different letters (a-d) above bars indicate treatment with significant differences throughout the seasons $(\mathrm{P}<0.05)$

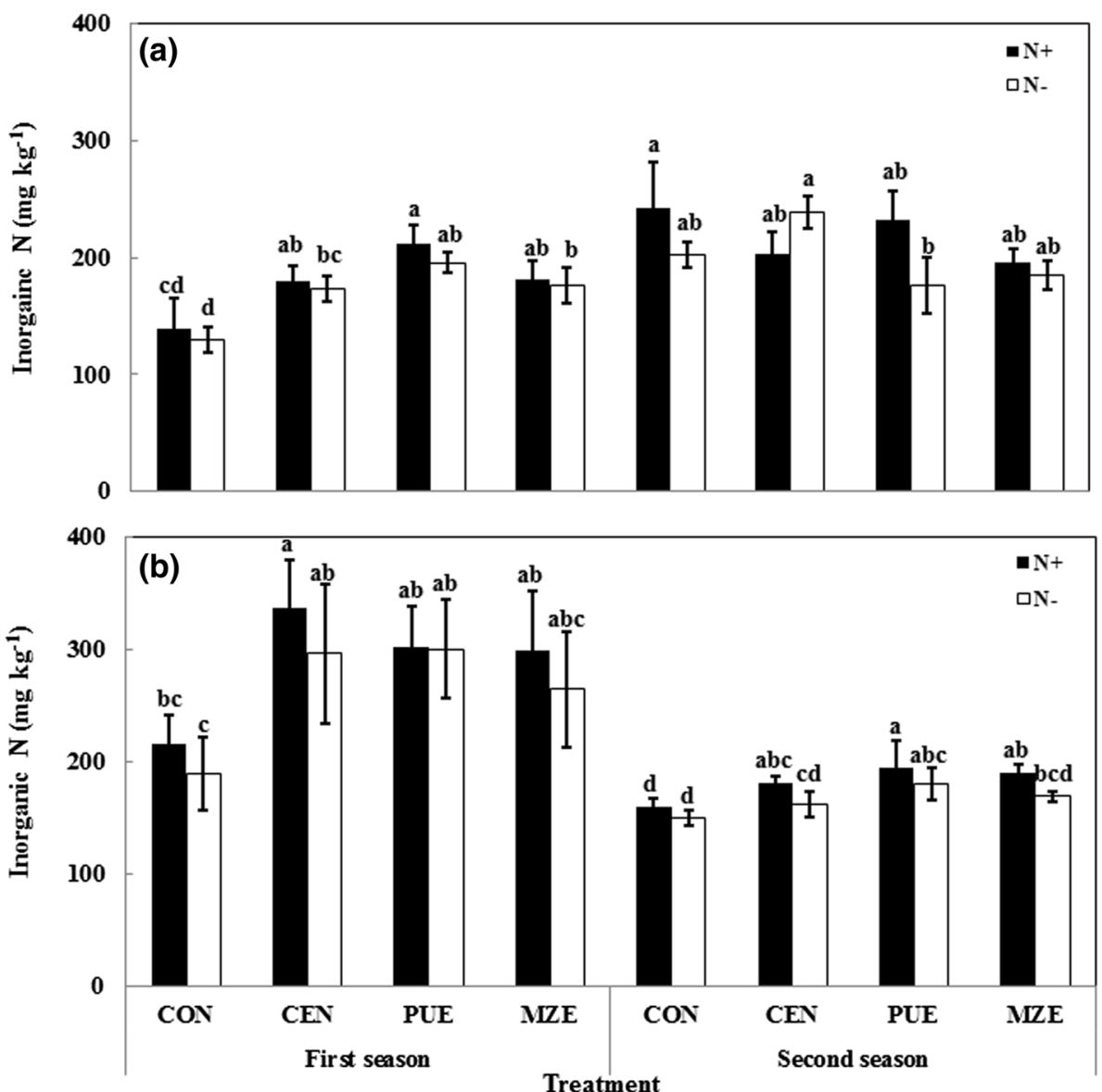


Table 7 Dissolved organic carbon following the addition of different OIs alone or in combination with $90 \mathrm{~kg} \mathrm{~N} \mathrm{ha}^{-1}$ chemical fertilizer

\begin{tabular}{|c|c|c|c|c|c|c|c|}
\hline \multicolumn{8}{|c|}{ Dissolved organic carbon $\left(\mathrm{mg} \mathrm{kg}^{-1}\right)$} \\
\hline \multirow[t]{2}{*}{ Treatment } & \multirow[t]{2}{*}{$\mathrm{N}$ fertilizer } & \multicolumn{3}{|l|}{ Tassel } & \multicolumn{3}{|l|}{ Harvest } \\
\hline & & First & Second & Average & First & Second & Average \\
\hline \multirow[t]{2}{*}{$\mathrm{CON}$} & 0 & $482.8 \pm 6.5^{\mathrm{ab}}$ & $354.3 \pm 9.2^{\mathrm{b}}$ & $418.6 \pm 7.9$ & $221.4 \pm 15.3^{\mathrm{a}}$ & $450.1 \pm 6.2^{\mathrm{cd}}$ & $335.8 \pm 10.8$ \\
\hline & 90 & $546.7 \pm 34.5^{\mathrm{a}}$ & $379.6 \pm 26.1^{\mathrm{b}}$ & $463.2 \pm 30.3$ & $247.8 \pm 36.9^{\mathrm{a}}$ & $482.8 \pm 4.3^{\mathrm{bc}}$ & $365.3 \pm 20.6$ \\
\hline \multirow[t]{2}{*}{ CEN } & 0 & $480.2 \pm 20.4^{\mathrm{ab}}$ & $415.9 \pm 8.9^{\mathrm{a}}$ & $448.1 \pm 14.7$ & $212.9 \pm 6.1^{\mathrm{a}}$ & $420.0 \pm 5.1^{\mathrm{d}}$ & $316.4 \pm 5.6$ \\
\hline & 90 & $472.2 \pm 46.9^{\mathrm{b}}$ & $296.9 \pm 5.0^{\mathrm{cd}}$ & $384.6 \pm 25.9$ & $236.4 \pm 1.6^{\mathrm{a}}$ & $461.0 \pm 10.3^{\mathrm{c}}$ & $348.7 \pm 5.9$ \\
\hline \multirow[t]{2}{*}{ PUE } & 0 & $526.4 \pm 37.6^{\mathrm{ab}}$ & $313.9 \pm 8.3^{\mathrm{c}}$ & $420.2 \pm 22.9$ & $218.0 \pm 15.4^{\mathrm{a}}$ & $489.6 \pm 9.8^{\mathrm{bc}}$ & $353.8 \pm 12.6$ \\
\hline & 90 & $497.8 \pm 13.0^{\mathrm{ab}}$ & $274.8 \pm 11.1^{\mathrm{d}}$ & $386.3 \pm 12.1$ & $229.1 \pm 11.1^{\mathrm{a}}$ & $546.6 \pm 32.3^{\mathrm{a}}$ & $387.9 \pm 21.7$ \\
\hline \multirow[t]{2}{*}{ MZE } & 0 & $488.2 \pm 4.4^{\mathrm{ab}}$ & $360.2 \pm 17.5^{\mathrm{b}}$ & $424.2 \pm 11.0$ & $240.0 \pm 3.8^{\mathrm{a}}$ & $506.6 \pm 7.6^{\mathrm{b}}$ & $373.3 \pm 5.7$ \\
\hline & 90 & $478.7 \pm 7.5^{\mathrm{b}}$ & $298.8 \pm 8.6^{\mathrm{cd}}$ & $388.8 \pm 8.1$ & $228.0 \pm 26.4^{\mathrm{a}}$ & $521.4 \pm 7.9^{\mathrm{ab}}$ & $374.7 \pm 17.2$ \\
\hline Means & & 496.6 & 336.8 & & 229.2 & 484.8 & \\
\hline MSD & & 67.1 & 34.6 & & 54.7 & 39.6 & \\
\hline CV (\%) & & 4.7 & 3.6 & & 8.3 & 2.8 & \\
\hline $\mathrm{R}^{2}$ & & 0.70 & 0.96 & & 0.39 & 0.92 & \\
\hline
\end{tabular}

Different letters $(\mathrm{a}, \mathrm{b})$ in the same column indicate treatments with significant differences within the same season $(\mathrm{P}<0.05)$

Treatments codes: CON control, CEN Centrosema pubescens, PUE Pueraria pubescens, MZE Zea mays, MSD minimum significant difference, $C V$ coefficient of variation

Fig. 4 Soil microbial biomass $C$ (MBC) at a tassel and $\mathbf{b}$ at harvest in both growing seasons. Treatment codes: $C O N$ control, CEN Centrosema pubescens, PUE Pueraria phaseoloides, MZE Zea mays. Different letters (a-d) above bars indicate treatment with significant differences throughout the seasons $(\mathrm{P}<0.05)$

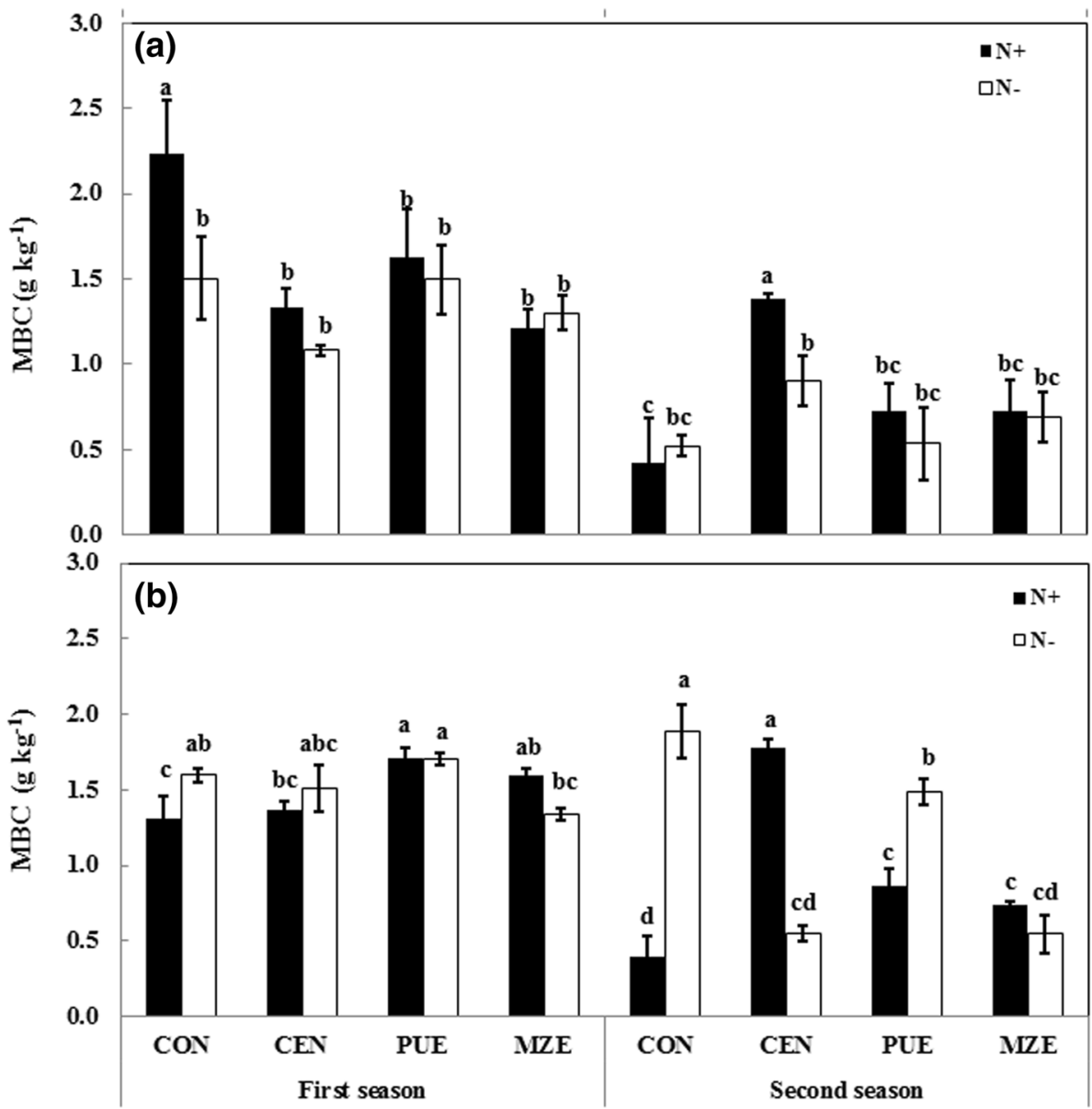

Treatment 


\section{Soil microbial biomass carbon and nitrogen}

The addition of OIs or in combination with CF had significant effects on $\mathrm{MBC}$ at tasselling and at harvest in both growing seasons (Fig. 4). Soil MBC ranged from $1.1 \mathrm{~g} \mathrm{~kg}^{-1}$ to $2.2 \mathrm{~g} \mathrm{~kg}^{-1}$ from tassel to harvest, respectively in the first season. In the second season, MBC ranged from $0.4 \mathrm{~g} \mathrm{~kg}^{-1}$ to $1.9 \mathrm{~g} \mathrm{~kg}^{-1}$ from tassel to harvest, respectively. At tassel, $\mathrm{CF}$ addition to OIs did not enhance MBC contents except in CEN amendment during the second season (Fig. 4a). The $\mathrm{CON}+$ treatment showed the highest MBC of $2.2 \mathrm{~g} \mathrm{~kg}^{-1}$ in the first season. However, in the second season, the highest MBC of $1.4 \mathrm{~g} \mathrm{~kg}^{-1}$ was observed in the CEN+ treatment. At harvest, the influence of CF application with OIs on soil $\mathrm{MBC}$ was seen in CEN and PUE during the second season (Fig. 4b). While CF addition suppressed MBC content in PUE, a significant improvement was observed in CEN treatment. In the first season, PUE+ and PUE- showed the highest $\mathrm{MBC}$ while, in the second season, $\mathrm{CON}$ - showed the highest MBC of $1.9 \mathrm{~g} \mathrm{~kg}^{-1}$ and was four times higher compared to $\mathrm{CON}+$.

Treatments application had significant influences on MBN at all sampling times, except at tassel during the first season (Fig. 5). Similar to soil MBC, the average MBN values observed in the first season was higher than that in the second season, regardless of treatment type. While $\mathrm{CF}$ addition to OIs showed significant increases in MBN at harvest, no significant effects were observed at tassel. In the first season at harvest, high MBN of $157.5 \mathrm{mg} \mathrm{kg}^{-1}$ was observed in MZE+ and was almost thrice higher compared to MZE - (Fig. 5b). In the second season, the highest MBN of $155.3 \mathrm{mg} \mathrm{kg}^{-1}$ was observed in the CEN+ treatment.

The results of the ANOVA are summarized in Table 8. The results showed significant independent and interaction effects on grain and straw yield for the factors "OIs," "CFs," and "Seasons" $(\mathrm{P}<0.05)$, except for non-significant $\mathrm{OI} \times \mathrm{CFs} \times$ Seasons interaction $(\mathrm{P}>0.05)$ on straw yield. Similarly, EON and mineral $\mathrm{N}$ revealed significant independent and interaction effects among the factors "OIs," "CFs," and "Seasons." However, soil DOC showed no interaction among the factors "OIs," "CFs," and "Seasons," except for a significant organic input $\times$ seasons interaction. Moreover, there was significant OIs $\times$ CFs $\times$ Seasons interaction on soil microbial biomass.
Fig. 5 Soil microbial biomass $\mathrm{N}$ (MBC) at a tassel and $\mathbf{b}$ at harvest in both growing seasons. Treatment codes: $C O N$ control, CEN Centrosema pubescens, PUE Pueraria phaseoloides, MZE Zea mays. Different letters (a-d) above bars indicate treatment with significant differences throughout the seasons $(\mathrm{P}<0.05)$
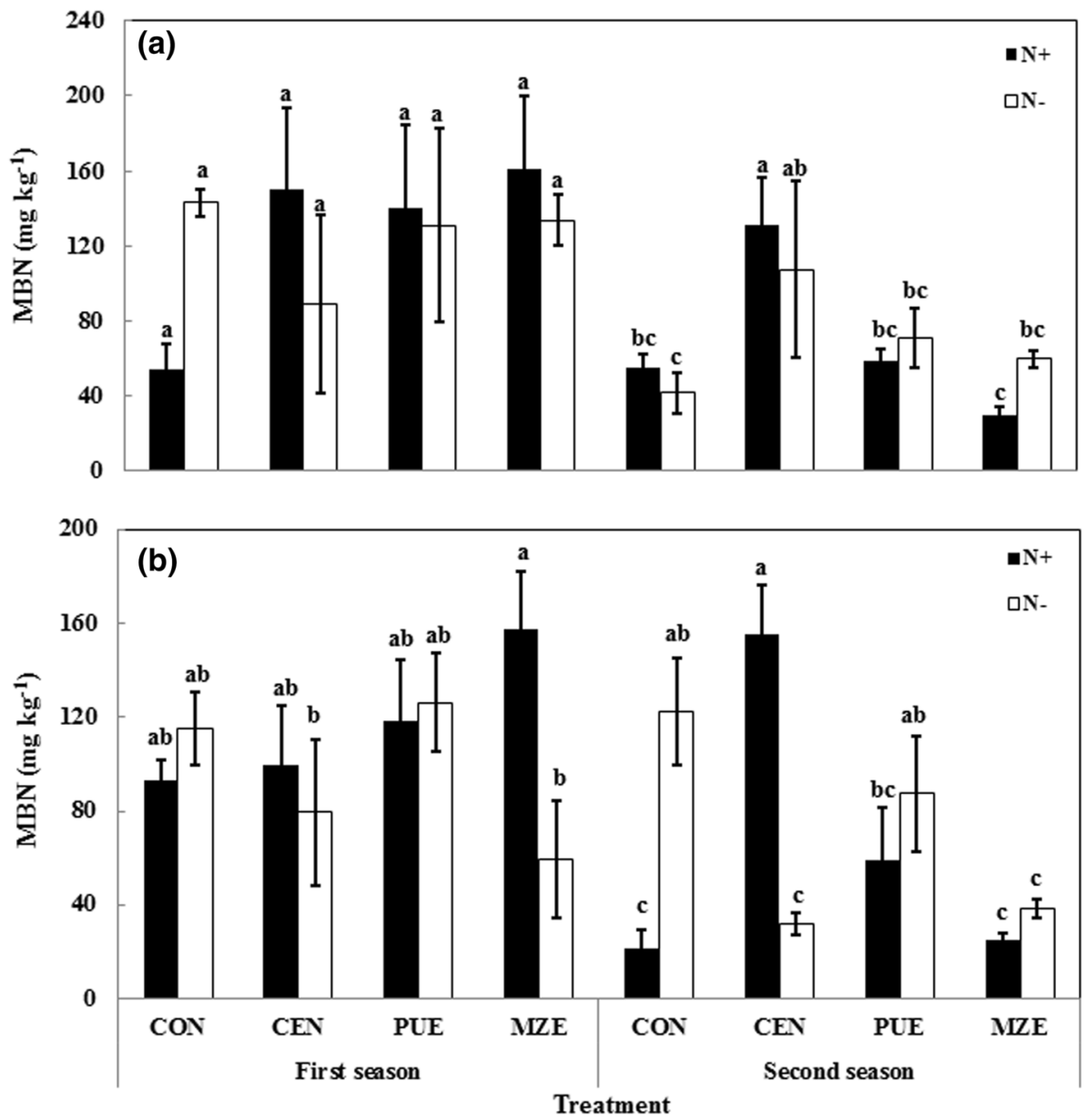
Table 8 ANOVA results for the effect of contrasting organic resources with or without chemical fertilizers on grain yield and soil properties

\begin{tabular}{llllllll}
\hline Source of variation & $\mathrm{MBC}$ & $\mathrm{MBN}$ & $\mathrm{DOC}$ & $\mathrm{EON}$ & $\mathrm{MN}$ & Grain yield & Straw yield \\
\hline Organic input (OI) & $* * *$ & $*$ & $\mathrm{~ns}$ & $*$ & $* * *$ & $* * *$ & $* * *$ \\
Chemical fertilizer (CF) & $\mathrm{ns}$ & $\mathrm{ns}$ & $\mathrm{ns}$ & $* * *$ & $* * *$ & $* * *$ & $* * *$ \\
Season (SE) & $* * *$ & $* * *$ & $* * *$ & $* * *$ & $* * *$ & $* * *$ & $* * *$ \\
$\mathrm{OI} \times \mathrm{CF}$ & $* * *$ & $* * *$ & $\mathrm{~ns}$ & $* * *$ & $\mathrm{~ns}$ & $* * *$ & $*$ \\
$\mathrm{OI} \times \mathrm{SE}$ & $* * *$ & $* * *$ & $\mathrm{~ns}$ & $* * *$ & $* * *$ & $* * *$ & $* * *$ \\
$\mathrm{CF} \times \mathrm{SE}$ & $\mathrm{ns}$ & $\mathrm{ns}$ & $*$ & $* * *$ & $\mathrm{~ns}$ & $* * *$ & $* *$ \\
$\mathrm{OI} \times \mathrm{CF} \times \mathrm{SE}$ & $* * *$ & $* *$ & $\mathrm{~ns}$ & $* * *$ & $*$ & $* * *$ & $\mathrm{~ns}$ \\
\hline
\end{tabular}

Factors: organic input (OI) (CEN, PUE, MZE, CON); chemical fertilizer (CF) $\left(0 \mathrm{~kg} \mathrm{~N}, 90 \mathrm{~kg} \mathrm{~N} \mathrm{ha}^{-1}\right)$; season (SE) (major, minor)

Soil parameter: $M B C$ microbial biomass $\mathrm{C}, M B N$ microbial biomass $\mathrm{N}, D O C$ dissolved organic carbon, EON extractable organic nitrogen, $M N$ mineral $\mathrm{N}$

Significance levels: $* * * \mathrm{P}<0.1 \%, * * \mathrm{P}<1 \%, * \mathrm{P}<5 \%$, ns not significant

\section{Discussion}

\section{Effects of treatments and seasonal differences on maize straw and grain yield}

Seasonal rainfall amount and distribution directly accounted for the maize grain yield and aboveground biomass disparities between the two seasons. As shown in the results, cumulative rainfall amount of $460 \mathrm{~mm}$ was received in the second season (September-January) as against $750 \mathrm{~mm}$ in the first (March-July). This created limiting moisture conditions in the second season, which possibly hindered the impacts of OIs on maize yield although they have been reported to possess greater residual benefits on crop yield (Diacono and Montemurro 2010; Chivenge et al. 2011b).

The $\mathrm{P}$ and $\mathrm{K}$ contents in the OIs were significantly low. Thus, $\mathrm{N}$ input differences from the OIs presents the most likely reasons for the observed disparities in maize growth and yield among the treatments. This indicates that the increased yields in MZE + and CEN+ treatments relative to their corresponding sole OIs were likely due to the higher resource $\mathrm{N}$ inputs. Among the combined treatments, maize grain yield and interactive effects differed in both seasons, presumably due to the synergy from their combination as exhibited in $\mathrm{N}$ release pattern or moisture retention abilities.

The MZE residue, given its low $\mathrm{N}$ but high $\mathrm{CN}$ ratio decomposes slowly relative to the high-quality CEN and PUE. Hence, the immediate $\mathrm{N}$ need of maize plant at the initial growth period was met by the CF while the MZE inputs supplemented subsequent $\mathrm{N}$ needs. The relatively high decomposition rate in the high-quality PUE amendment suggests that probably more than enough mineral $\mathrm{N}$ was available during plant growth and might have been lost through leaching or denitrification during peaks in rainfall. The present results suggest for the sole application of either PUE or CEN, because extra CF addition would have minimal impacts on crop yield. This result is in accord with several reports elsewhere employing high-quality OIs with CFs. For example, Vanlauwe et al. (2001) observed negative interactive effects on maize yield following the combined application of Mucuna pruriens with CFs. Additionally, similar responses on maize grain yield were observed by Chivenge et al. (2009) and Gentile et al. (2011) when litter from high-quality Tithonia diversifolia was applied in combination with $\mathrm{CF}$ in fertile soil. In contrast to the supposed excess mineral $\mathrm{N}$ in PUE with $\mathrm{CF}$ amendments, lowest crop yield values observed for low-quality MZE is attributed to $\mathrm{N}$ limitation caused by nutrient immobilization as a result of its high $\mathrm{CN}$ ratio.

Moisture dynamics played a significant role in the observed yield interactive effects. The low-quality MZE with CF presented more significant benefits on maize yield in low rainfall or dry climates. On the other hand, the sole application of high-quality PUE and CEN in moist climates reasonably improved $\mathrm{N}$ utilization efficiency in maize. Thus, the benefit of CF addition to OIs is not only dependent on residue quality but also the prevailing soil moisture content in which the resources are amended.

\section{Chemical fertilizer and organic input on soil carbon and nitrogen dynamics}

High rainfall amount of $750 \mathrm{~mm}$ received during the first season enhanced litter mineralization and $\mathrm{N}$ release to maize plants. Moreover, the statistically similar soil EON and mineral $\mathrm{N}$ contents from CEN and PUE amendments at most samplings as a function of the small maize grain yield increase following $\mathrm{CF}$ addition emphasize the need for the sole application of high-quality OIs for enhanced $\mathrm{N}$ utilization efficiency (Palm et al. 2001; Gentile et al. 2011). This may, however, be practicable in relatively fertile soil in the short term. The sole CEN and PUE treatments, characterized by low polyphenols, showed higher $\mathrm{N}$ recovery compared to MZE-, contradicting the claim that polyphenols have no 
significant influence on $\mathrm{N}$ mineralization in field conditions (Chivenge et al. 2011b).

Adequate soil moisture in the first season enhanced early phase microbial activity, resulting in the loss of soluble $\mathrm{C}$ forms. This subsequently led to a significant reduction in DOC content at harvest in the same season. In contrast, the observed water unavailability in the second season resulted in reduced microbial activity, leading to an increased $\mathrm{C}$ forms from tassel to harvest. These observations agree with the general understanding that adequate soil moisture regimes are essential factors for litter decomposition and $\mathrm{C}$ sequestration (Brady and Weil 2008).

The initial DOC increase in the sole OI treatments as opposed to losses in the combined amendments suggest enhanced litter decomposition as a result of $\mathrm{CF}$ addition. This observation is explained by the fact that the early phase decomposition of OIs after CF addition triggered assimilation of DOC by soil microbes for energy and synthesis. Similarly, Chivenge et al. (2011a) observed higher C losses following CF co-application with OIs. On the other hand, $\mathrm{CF}$ addition to $\mathrm{OI}$ resulted in increased DOC stocks in the combined treatments at harvest due to higher $\mathrm{C}$ inputs from roots and aboveground portions of the maize plant. In a long term study, Wei et al. (2016) and Bedada et al. (2014) also observed higher SOM and DOC contents respectively, following combined application of OIs with CFs compared to solely applied OIs. The present study thus suggests that soil moisture and time factor, which distinguished tassel from harvest in the present study, played a significant role in the influence of CF on OI decomposition. Hence, future studies should invest in long-term evaluations of the present OIs, alone or in combination with CFs to unravel their potential $\mathrm{C}$ and $\mathrm{N}$ contribution to the soil.

\section{Treatment effects on soil microbial biomass content}

Adequate rainfall amount received during the first season enhanced the activities of microbes and thus facilitated their access to substrates (Schjønning et al. 2003; Dungait et al. 2012; Manzoni et al. 2012). Although CF either as 0 or $90 \mathrm{~kg} \mathrm{~N} \mathrm{ha}^{-1}$ showed no significant effects on soil microbial biomass, its co-application with OIs resulted in varying microbial biomass pools. The microbial biomass responses varied with OI type and sampling times, reiterating the influence of climatic variables and litter chemistry on microbial biomass dynamics (Brady and Weil 2008; Omari et al. 2018b).

The effect of CF alone or its combination with OIs on microbial biomass was more evident at harvest, especially during the second season characterized by low soil moisture. This observation is likely, because the low soil moisture concentrated the CF constituents, resulting in traces which suppressed soil microbial activities. Similarly, Muema et al. (2016) ascribed a 35\% decrease in ammonia-oxidizing archaea abundance to rhizosphere $\mathrm{pH}$ reduction due to the sole application of $\mathrm{CF}$ or its combination with OIs. Also, the opposing responses in microbial biomass content in CEN and PUE following co-application with $\mathrm{CF}$ reflects differences in their inherent residue quality characteristics. The allelochemicals of CEN and PUE may likely have formed different complexes with CF which enhanced or suppressed microbial biomass pools, respectively. Moreover, at most sampling times, while CF application with CEN improved microbial biomass, solely applied CEN suppressed soil microbial biomass. This supports the earlier claim that CF addition to OIs could potentially alter its allelopathic abilities.

\section{Conclusion}

The present results confirmed the positive synergistic effect of combined application of CFs with OIs on maize yield and soil properties. As inferred from the results, the impact of CF input on maize yield and soil properties differed with season and quality of OIs. CF addition with low-quality MZE residues synergistically enhanced maize yield comparable to $\mathrm{CON}+$. However, negative interactive effects, characterized by more significant responses in the second season, were observed in the high-quality CEN and PUE amendments. Thus, from the present study, it would be much beneficial to encourage amendments of low-quality organic resources with additional CFs in dry climates. Similarly, amendment of high-quality OIs such as CEN in moist climates is recommended to reduce $\mathrm{N}$ use inefficiency. The DOC and EON dynamics following $\mathrm{CF}$ addition to OIs were dependent on seasonal soil moisture differences and time of sampling. Chemical application to OIs revealed opposing responses on soil microbial biomass. For instance, CF application to CEN triggered microbial activity, whereas its co-application with MZE and PUE suppressed soil microbial biomass. Although CF with MZE or CEN represents the most effective combination for improved maize yield, the observed response was mainly ascribed to the effects of CF addition. Thus, while the present study encourages the use of CEN and MZE residues with CF among farmers to enhance soil and crop productivity, long-term trials would be required to unravel the best strategy to manage such resources, for agro-ecosytems sustainability.

Acknowledgments Open Access funding provided by Projekt DEAL.

\section{Compliance with ethical standards}

Conflict of interest The authors declare no conflict of interest. 
Open Access This article is licensed under a Creative Commons Attribution 4.0 International License, which permits use, sharing, adaptation, distribution and reproduction in any medium or format, as long as you give appropriate credit to the original author(s) and the source, provide a link to the Creative Commons licence, and indicate if changes were made. The images or other third party material in this article are included in the article's Creative Commons licence, unless indicated otherwise in a credit line to the material. If material is not included in the article's Creative Commons licence and your intended use is not permitted by statutory regulation or exceeds the permitted use, you will need to obtain permission directly from the copyright holder. To view a copy of this licence, visit http://creativecommons.org/licenses/by/4.0/.

\section{References}

Abera G, Wolde-meskel E, Bakken LR (2012) Carbon and nitrogen mineralization dynamics in different soils of the tropics amended with legume residues and contrasting soil moisture contents. Biol Fertil Soils 48:51-66

Adjei-Gyapong T, Asiamah RD (2002) The interim Ghana soil classification system and its relation with the World Reference Base for Soil Resources. FAO Rep Soil Resour 98:9-13

Asante M, Becker M, Angulo C, Fosu M, Dogbe W (2017) Seasonal nitrogen dynamics in lowland rice cropping systems in inland valleys of northern Ghana. J Plant Nutr Soil Sci 180:87-95

Bedada W, Karltun E, Lemenih M, Tolera M (2014) Long-term addition of compost and NP fertilizer increases crop yield and improves soil quality in experiments on smallholder farms. Agric Ecosyst Environ 195:193-201

Boakye-Danquah J, Antwi EK, Saito O, Abekoe MK, Takeuchi K (2014) Impact of farm management practices and agricultural land use on soil organic carbon storage potential in the savannah ecological zone of northern Ghana. J Disaster Res 9:484-500

Brady CN, Weil RR (2008) The Nature and properties of soil, 14th edn. Pearson Education Inc, New Jersey (Pearson Prentice Hall, Upper saddle river)

Brookes PC, Landman A, Pruden G, Jenkinson DS (1985) Chloroform fumigation and the release of soil nitrogen: a rapid direct extraction method to measure microbial biomass nitrogen in soil. Soil Biol Biochem 17(6):837-842. https://doi.org/10.1016/00380717(85)90144-0

Chivenge P, Vanlauwe B, Gentile R, Wangechi H, Mugendi D, van Kessel C, Six J (2009) Organic and mineral input management to enhance crop productivity in central Kenya. Agron J 101:1266-1275

Chivenge P, Vanlauwe B, Gentile R, Six J (2011a) Organic resource quality influences short-term aggregate dynamics and soil organic carbon and nitrogen accumulation. Soil Biol Biochem 43:657-666

Chivenge P, Vanlauwe B, Six J (2011b) Does the combined application of organic and mineral nutrient sources influence maize productivity? A meta-analysis. Plant Soil 342:1-30

Diacono M, Montemurro F (2010) Long-term effects of organic amendments on soil fertility. A review. Agron Sustain Dev 30:401-422

Dungait JAJ, Hopkins DW, Gregory AS, Whitmore AP (2012) Soil organic matter turnover is governed by accessibility not recalcitrance. Glob Change Biol 18:1781-1796

FAO/ISRIC/ISSS (1998) World reference base for soil resources (WRB). World soil resources report 84. International Society of Soil Science, International Soil Reference and Information Centre, and Food and Agriculture Organization of the United Nations, Rome

Ge G, Li Z, Fan F, Chu G, Hou Z, Liang Y (2010) Soil biological activity and their seasonal variations in response to long-term application of organic and inorganic fertilizers. Plant Soil 326:31-44
Gentile R, Vanlauwe B, Chivenge P, Six J (2008) Interactive effects from combining fertilizer and organic residue inputs on nitrogen transformations. Soil Biol Biochem 40:2375-2384

Gentile R, Vanlauwe B, Chivenge P, Six J (2011) Trade-offs between the short- and long-term effects of residue quality on soil $\mathrm{C}$ and N dynamics. Plant Soil 338:159-169

Gomez KA, Gomez AA (1984) Statistical procedures for agricultural research, 2nd edn. Wiley, New York

Hobbie SE (1998) Chloroform fumigation direct extraction (CFDE) protocol for microbial biomass carbon and nitrogen. https://web. stanford.edu/group/Vitousek/chlorofume.html Accessed $10 \mathrm{Apr}$ 2018

Joergensen RG (1996) The fumigation-extraction method to estimate soil microbial biomass: calibration of the KEC factor. Soil Biol Biochem 28:25-31

Kamaa M, Mburu H, Blanchart E, Chibole L, Chotte JL, Kibunja C, Lesueur D (2011) Effects of organic and inorganic fertilization on soil bacterial and fungal microbial diversity in the Kabete longterm trial, Kenya. Biol Fertil Soils 47:315-321

Kanonge G, Mtambanengwe F, Manzeke MG, Nezomba H, Mapfumo $\mathrm{P}$ (2015) Assessing the potential benefits of organic and mineral fertiliser combinations on legume productivity under smallholder management in Zimbabwe. South Afr J Plant Soil 32:241-248

Keiblinger K, Hall EK, Wanek W, Szukics U, Hammerle I, Ellersdorfer G, Bock S, Strauss J, Sterflinger K, Richter A, ZechmeisterBolternstern S (2010) The effect of resource quantity and resource stoichiometry on microbial carbon-use-efficiency. FEMS Microbiol Ecol 73:430-440

Manzoni S, Schimel JP, Porporato A (2012) Responses of soil microbial communities to water stress: results from a meta-analysis. Ecology 93:930-938

Muema EK, Cadisch G, Musyoki MK, Rasche F (2016) Dynamics of bacterial and archaeal amoA gene abundance after additions of organic inputs combined with mineral nitrogen to an agricultural soil. Nutr Cycl Agroecosyst 104:143-158

Nelson DW, Sommers LE (1996) Total carbon, organic carbon and organic matter. In: Sparks DL, Page AL, Helmke PA, Loeppert RH (eds) Methods of soil analyses, part 3, chemical methods. Soil Sci Soc Am, Madison, pp 961-1010

Omari RA, Aung HP, Hou M, Yokoyama T, Onwona-Agyeman S, Oikawa Y, Fujii Y, Bellingrath-Kimura SD (2016) Influence of different plant materials in combination with chicken manure on soil carbon and nitrogen contents and vegetable yield. Pedosphere 26:510-521

Omari RA, Sarkodee-Addo E, Fujii Y, Oikawa Y, Bellingrath-Kimura S (2017) Impacts of Fertilization type on soil microbial biomass and nutrient availability in two agroecological zones of Ghana. Agronomy 7:55

Omari RA, Bellingrath-Kimura SD, Sarkodee-Addo E, Oikawa Y, Fujii Y (2018a) Exploring farmers' indigenous knowledge of soil quality and fertility management practices in selected farming communities of the Guinea Savannah agro-ecological zone of Ghana. Sustainability 10:1034

Omari RA, Bellingrath-Kimura SD, Fujii Y, Sarkodee-Addo E, Sarpong KA, Oikawa Y (2018b) Nitrogen mineralization and microbial biomass dynamics in different tropical soils amended with contrasting organic resources. Soil sys 2:63

Palm CA, Gachengo CN, Delve RJ, Cadisch G, Giller KE (2001) Organic inputs for soil fertility management in tropical agro ecosystems: application of an organic resource database. Agric Ecosyst Environ 83:27-42

Parsons TR, Maita Y, Lalli CM (1984) A manual of chemical and biological methods for seawater analysis, 1st edn. Pergamon Press, Oxford

Partey ST, Preziosi RF, Robson GD (2014) Short-term interactive effects of biochar, green manure, and inorganic fertilizer on soil 
properties and agronomic characteristics of maize. Agric Res 3:128-136

Ros GH, Hoffland E, van Kessel C, Temminghoff EJM (2009) Extractable and dissolved soil organic nitrogen: a quantitative assessment. Soil Biol Biochem 41:1029-1039

Schjønning P, Thomsen IK, Moldrup P, Christensen BT (2003) Linking soil microbial activity to water- and air-phase contents and diffusivities. Soil Sci Soc Am J 67:156-165

Shen JP, Zhang LM, Guo JF, Ray JL, He JZ (2010) Impact of longterm fertilization practices on the abundance and composition of soil bacterial communities in Northeast China. Appl Soil Ecol 46:119-124

Sinsabaugh RL, Hill BH, Shah FJ (2010) Ecoenzymatic stoichiometry of microbial organic nutrient acquisition in soil and sediment. Nature 462:795-798

Truog E (1930) The determination of the readily available phosphorus of soils. Agron J 22:874-882

US Environmental Protection Agency (1983) Methods for chemical analysis of water and wastes. Environmental Protection Agency, Washington, p 491
Vanlauwe B, Wendt J, Diels J (2001) Combined application of organic matter and fertilizer. In: Tian G, Ishida F, Keatinge D (eds) Sustaining soil fertility in West Africa, vol 58. Soil Sci Soc Am Special Publication, Madison, pp 247-279

Vanlauwe B, Bationo A, Chianu J, Giller KE, Merckx R, Mokwunye U, Ohiokpehai O, Pypers P, Tabo R, Shepherd KD, Smaling EMA, Woomer PL, Sanginga N (2010) Integrated soil fertility management: operational definition and consequences for implementation and dissemination. Outlook Agric 39:17-24

Wei W, Yana Y, Cao J, Christie P, Zhang F, Fan M (2016) Effects of combined application of organic amendments and fertilizers on crop yield and soil organic matter: an integrated analysis of longterm experiments. Agric Ecosyst Environ 225:86-92

Yang ZC, Zhao N, Huang F, Lv YZ (2015) Long-term effects of different organic and inorganic fertilizer treatments on soil organic carbon sequestration and crop yields on the North China Plain. Soil Tillage Res 146:47-52

Publisher's Note Springer Nature remains neutral with regard to jurisdictional claims in published maps and institutional affiliations. 